\title{
Low-laser light therapy in venous ulcer healing: a randomized clinical trial
}

Terapia a laser de baixa potência na cicatrização de úlcera venosa: ensaio clínico randomizado

Terapia adyuvante por luz de baja intensidad en la cicatrización de úlceras varicosas: un ensayo clínico aleatorizado

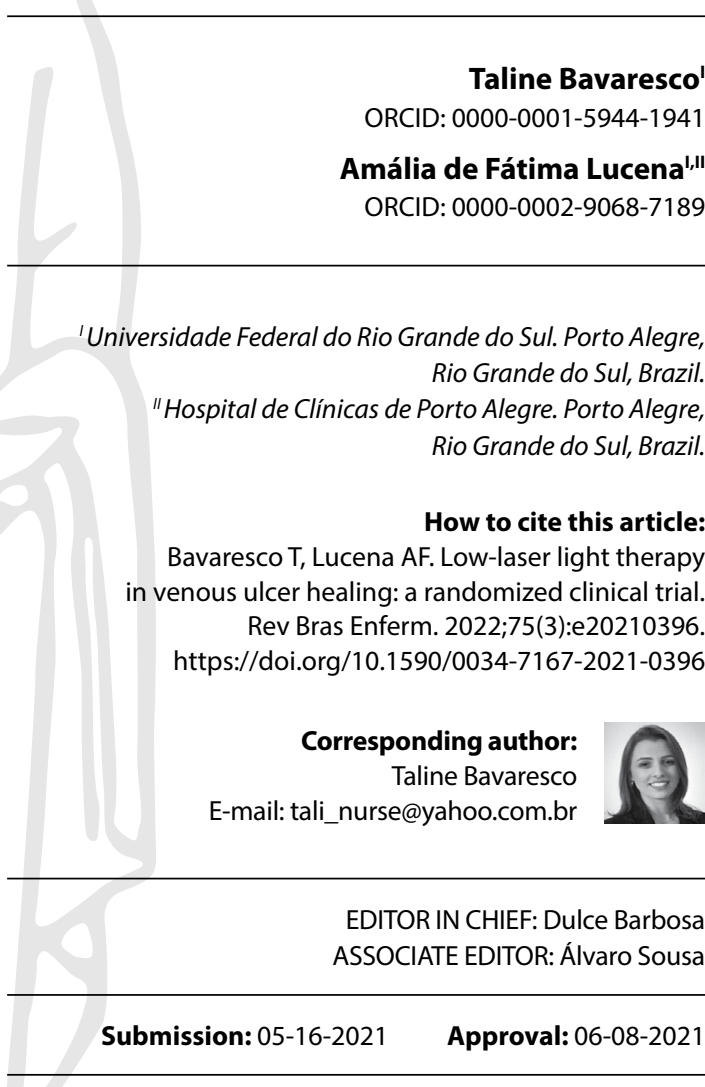

\begin{abstract}
Objectives: to compare the effect of adjuvant low-laser light therapy versus conventional treatment alone on venous ulcer healing. Methods: this is a randomized clinical trial with 40 patients randomized equally to a control group (topical and compressive treatment) and intervention group (adjuvant low-laser light therapy). Outcomes of interest were Wound Healing: Secondary Intention and Tissue Integrity: Skin \& Mucous Membranes, as described in the Classification of Nursing Outcomes/NOC. Results: groups with similar sociodemographic and clinical characteristics. Eighty-two ulcers were assessed, with an average duration of 1 to 5 years, in 1,066 nursing consultations, with a statistically significant difference in the time and number of healed ulcers (intervention group). There was a significant improvement in the nursing outcomes under study and in eight clinical indicators. Conclusions: low-laser light therapy improves and reduces tissue regeneration time, contributing to advances in wound treatment.

Descriptors: Venous Ulcer; Low-Laser Light Therapy; Wound Healing; Standardized Nursing Terminology; Outcome Assessment.
\end{abstract}

\section{RESUMO}

Objetivos: comparar o efeito da terapia a laser de baixa potência adjuvante versus o tratamento convencional isolado na cicatrização de úlcera venosa. Métodos: ensaio clínico randomizado com 40 pacientes aleatorizados igualmente para grupo controle (tratamento tópico e compressivo) e grupo intervenção (terapia a laser de baixa potência adjuvante). Os desfechos de interesse foram Cicatrização de Feridas: Segunda Intenção e Integridade Tissular: Pele e Mucosas, conforme descritos na Classificação de Resultados de Enfermagem/ NOC. Resultados: grupos com características sociodemográficas e clínicas semelhantes. Avaliadas 82 úlceras, com duração média de 1 a 5 anos, em 1.066 consultas de enfermagem, com diferença estatística significativa no tempo e no número de úlceras cicatrizadas (grupo intervenção). Houve melhora significativa nos resultados de enfermagem em estudo e em oito indicadores clínicos. Conclusões: a terapia com laser de baixa potência proporciona melhora e reduz o tempo de regeneração tecidual, contribuindo para o avanço no tratamento de feridas. Descritores: Úlcera Venosa; Terapia a Laser Baixa Potência; Cicatrização; Terminologia Padronizada de Enfermagem; Avaliação de Resultados.

\section{RESUMEN}

Objetivos: comparar el efecto de la terapia adyuvante por luz de baja intensidad versus tratamiento convencional solo sobre la cicatrización de la úlcera varicosa. Métodos: ensayo clínico aleatorizado con 40 pacientes aleatorizados igualmente al grupo de control (tratamiento tópico y compresivo) y al grupo de intervención (terapia adyuvante por luz de baja intensidad). Los resultados de interés fueron Curación de heridas: segunda intención e integridad del tejido: piel y mucosas, como se describe en la Clasificación de Resultados de Enfermería/NOC. Resultados: grupos con características sociodemográficas y clínicas similares. Se evaluaron 82 úlceras, con una duración promedio de 1 a 5 años, en 1.066 consultas de enfermería, con diferencia estadísticamente significativa en el tiempo y número de úlceras cicatrizadas (grupo de intervención). Hubo una mejora significativa en los resultados de enfermería en estudio y en ocho indicadores clínicos. Conclusiones: la terapia por luz de baja intensidad mejora y reduce el tiempo de regeneración tisular, contribuyendo a los avances en el tratamiento de heridas.

Descriptores: Úlcera Varicosa; Terapia por Luz de Baja Intensidad; Cicatrización de Heridas; Terminología Normalizada de Enfermería; Evaluación de Procesos. 


\section{INTRODUCTION}

Venous ulcer (VU) is a type of chronic leg wound that affects 0.5 to $2.2 \%$ of the adult population and 3 to $5 \%$ of those over 65 years old ${ }^{(1)}$. Overall, $93 \%$ of VUs heal within 12 months, but the remaining $7 \%$ persist for 5 years or more. The recurrence rate within 3 months after wound closure is approximately $70 \%(2)$.

The proper treatment of these ulcers is a search for the ideal healing process, and must take into account the different phases of these highly contaminated and proteolytic wounds as well as the various therapeutic modalities available ${ }^{(3)}$. The current conventional pattern involves a combination of topical dressings and compression therapy.

However, in many cases, conventional treatment fails to produce good results, and new approaches are needed. Low-laser light therapy (LLLT), which promotes photochemical effects on irradiated tissues, has emerged as an alternative for wound treatment ${ }^{(4)}$. LLLT is nonionizing, collimable, polarized, monochromatic, coherent light and can modify cell behavior to facilitate tissue repair. Its mechanism of action starts during photoreception (i.e., the moment of irradiation) and lasts until a photoresponse is reached (clinical effects), i.e., when light energy is transformed into chemical energy. This, in turn, stimulates the irradiated cells, which can multiply, regenerate or secrete any mediators needed to achieve homeostasis ${ }^{(5-8)}$.

There is evidence that LLLT can facilitate the re-epithelialization of chronic wounds, accelerate healing and reduce pain ${ }^{(5-9)}$. In diabetic foot ulcers, it produced significant improvement in wound size, pain reduction, amputation prevention and accelerated healing, improving patient mobility ${ }^{(7)}$. LLLT has also been reported to reduce wound dimensions, increase epithelialization, and reduce secretion and odor in pressure injuries ${ }^{(7)}$. However, in VU treatment, which are highly prevalent wounds in health services, there is still little evidence of the effect of LLLT in studies with robust designs, which points to the need for additional research ${ }^{(9-10)}$.

It is also essential that such surveys include reliable assessments of the wound tissue repair process, preferably with standardized instruments ${ }^{(11-12)}$. Several instruments have been used in the research of chronic wounds, but this remains the exception and not the rule, which can make it difficult to interpret the outcomes obtained and compare between studies and also between treatments used.

An alternative worth exploring is the Nursing Outcomes Classification (NOC), a standardized language for health outcomes. Each outcome is structured with a name, definition, numeric code, set of indicators and a 5-point Likert-type measurement scale $^{(13)}$. Among the 540 that make up the NOC, two are of particular interest for wound research - Wound Healing: Secondary Intention (1103), comprising 18 indicators, and Tissue Integrity: Skin \& Mucous Membranes (1101), with 22 indicators. These outcomes assess cell and tissue regeneration in wounds and the physiological functions of skin and mucous membranes, respectively ${ }^{(13)}$. NOC has been used in wound repair studies, in which it has demonstrated clinical applicability in different scenarios ${ }^{(14-17)}$.

In this context, this study was designed to address two gaps in evidence: the paucity of research on the effects of LLLT on VU, despite promising outcomes for other types of chronic wounds; and the need for studies with more robust designs, using standardized instruments (such as the NOC) that are able to reliably assess and describe the effects of different therapies, to produce high-level evidence in wound care research.

Despite the treatment alternatives available today, many VUs have a time-consuming and arduous healing process. In this scenario, LLLT may be a useful alternative, given its well-known photochemical effects on tissue repair. However, evidence of its comparative effectiveness in relation to conventional treatment is still lacking ${ }^{(3,5)}$.

The use of standardized instruments in comparative studies of different wound treatment modalities is also very scarce ${ }^{(14,16)}$. Still, reliable assessment of wounds and their healing process is essential for producing reliable evidence, which can have a beneficial impact on patient outcomes and treatment monetary cost.

\section{OBJECTIVES}

To compare the effect of adjuvant low-laser light therapy versus conventional treatment alone on venous ulcer healing.

\section{METHODS}

\section{Ethical aspects}

The study was approved by an Institutional Review Board, complying with Resolution 466/2012 of the Brazilian National Health Council (Conselho Nacional de Saúde) and registered in ClinicalTrials.gov of the U.S. National Institutes of Health ${ }^{(18)}$.

\section{Study design, period, and place}

This is a randomized clinical study, guided by CONSORT, with two groups: intervention (IG), in which LLLT was used adjuvant to conventional treatment, and control (CG), in which conventional treatment was performed using of products and topical coverings and compression therapy ${ }^{(18)}$. The study was not blinded in the application of the intervention, due to the irradiation emitted by the laser light used in the IG.

The study was carried out in the outpatient nursing service of a university hospital in the city of Porto Alegre, RS, Brazil, with patients with active $\mathrm{VU}$, treated in the nursing consultation schedule of the institution's wound clinic. Data collection took place from 2016 to 2018.

\section{Population and sample: inclusion and exclusion criteria}

To calculate the estimated sample size, the Winpepi program, version 11.43, was used. The calculation of the sample size in each of the groups (intervention $x$ control) was able to detect the difference of one point in the score of the NOC outcomes as significant, considering the standard deviation. Each NOC outcome has indicators that are scored on five-point Likert scales (range 1 to 5), with the lowest score representing the worst possible state and the highest score representing the most desirable state after implementing the intervention. The change in one point in the NOC outcome, assessed by a Likert-type scale, characterizes a positive effect of the intervention implemented throughout the study, according to mixed linear models and generalized estimating equations ${ }^{(19)}$.

For calculation, a power of $80 \%$ and a significance level of $5 \%$ were considered, with an addition of $20 \%$ to possible losses and 
refusals, which resulted in a sample of 40 patients (20 in each group), based on previous studies ${ }^{(14-17)}$.

During outpatient nursing consultations, researchers assessed each patient's eligibility for the study. Once considered eligible, the patient was invited to participate in the study. Later, in an additional meeting with the research assistant, the patient was instructed to choose a sealed brown envelope, without external notes or identification that could refer to group allocation. The principal investigator was only blinded to group allocation, but not to the intervention. The envelope was opened by patients themselves. Patients were allocated by simple random selection into two groups, in a ratio of 1: 1: IG (LLLT) and CG (conventional treatment).

Adult patients (aged 18 years or older) who had an active VU and were available to attend weekly follow-up appointments at the outpatient clinic for 16 weeks or until wound healing (whichever occurs first were included). Patients with mixed ulcers, brace ulcers, body mass index (BMI) in the Grade 3 obesity range, active cancer treatment, erysipelas, cellulitis, lymphangitis, chronic lymphedema, chronic immunosuppressive and/or corticosteroid therapy, covered wound bed for more than $25 \%$ of coagulation necrosis or wounds in the final stage of epithelialization were excluded.

\section{Study protocol}

Both groups received the conventional treatment according to the institutional protocol, which included cleaning the lesion with warm saline solution at $0.9 \%$ in a jet and application of different topical products and technological coatings to maintain the moist environment, exudate absorption and microbial control indicated according to the characteristics of $\mathrm{VU}$ bed, edge and perilesional skin. Compressive therapy with standardized elastic bandage and non-pharmacological interventions such as guidance to alternate isometric exercises and rest, raise lower limbs, keep a food record and follow healthy lifestyle habits were also implemented.

In addition to conventional treatment, the IG received adjuvant LLLT. The laser Aluminum Gallium Indium Phosphorus - AIGalnP (Po - $30 \mathrm{~mW}$ ), from Inbramed', with $660 \mathrm{~nm}$ in length and power of $30 \mathrm{~mW}$, with an energy variation of $1-3$ joules $/ \mathrm{cm}^{2}$, in which the irradiation time is applied, was applied. calculated and controlled by the device itself, according to energy, measured in seconds. Irradiation was performed directly on the wound bed and edge and occasionally on the perilesional skin of the wound. This intervention was performed by the main investigator, who is qualified to use this technology, following all the recommendations of the phototherapy protocol.

Data were collected by the main researcher and two research assistants, previously trained in the use of data collection instruments. Also, a pilot test of the instrument was carried out, and, after checking the interobserver agreement, patient assessments were carried out, individually, by each assistant throughout the study.

The first part of the data collection instrument was limited to sociodemographic and clinical characteristics of patients, which were taken from electronic medical record and clinical examination.

The second part of the instrument was designed to assess the VU tissue repair process during treatment (conventional and adjuvant LLLT), based on the NOC framework ${ }^{(13)}$. For this, the outcome Wound Healing: Secondary Intention (1103) was used, with eight indicators (foul wound odor, macerated skin, surrounding skin erythema, periwound edema, granulation, decreased wound size, scar formation, and exudate) and the outcome Tissue Integrity: Skin \& Mucous Membranes (1101), with six indicators (abnormal pigmentation, thickness, necrosis, hydration, pain, and pruritus). These two nursing outcomes, considered the clinical outcomes of interest, were assessed by 14 clinical indicators.

Each indicator was measured using 5-point Likert scales ${ }^{(13)}$, with a conceptual and operational definition, validated by experts in previous studies ${ }^{(20-21)}$, with the aim of standardizing the assessment carried out by research assistants. Wound assessment was started before the beginning of treatment, being assessed weekly in both groups, until the ulcer had healed or for a maximum period of 16 weeks ${ }^{(22)}$.

\section{Analysis of results, and statistics}

Data were organized in Excel for Windows spreadsheets, using double-entry to ensure accuracy, and analyzed using the software SPSS, version 23.0. Categorical variables were expressed as absolute and relative frequencies and continuous variables were expressed as mean and standard deviation. Student's t-test was used to compare continuous variables between groups, while Fisher's exact test was used for categorical variables. Kaplan-Meier curve and analysis of covariance (ANCOVA) were used to assess the magnitude of effect size. Generalized estimating equations were used to compare Likert scale scores for NOC outcome indicators. P-values of $<0.05$ were considered statistically significant.

\section{RESULTS}

Forty patients participated in the study, 20 of which were allocated to the IG (with $43 \mathrm{VU}$ ) and 20 to the CG (with $39 \mathrm{VU}$ ). There were 1,066 weekly nursing consultations, 551 for CG patients and 515 for IG patients, during a follow-up period of up to 16 weeks (Figure 1).

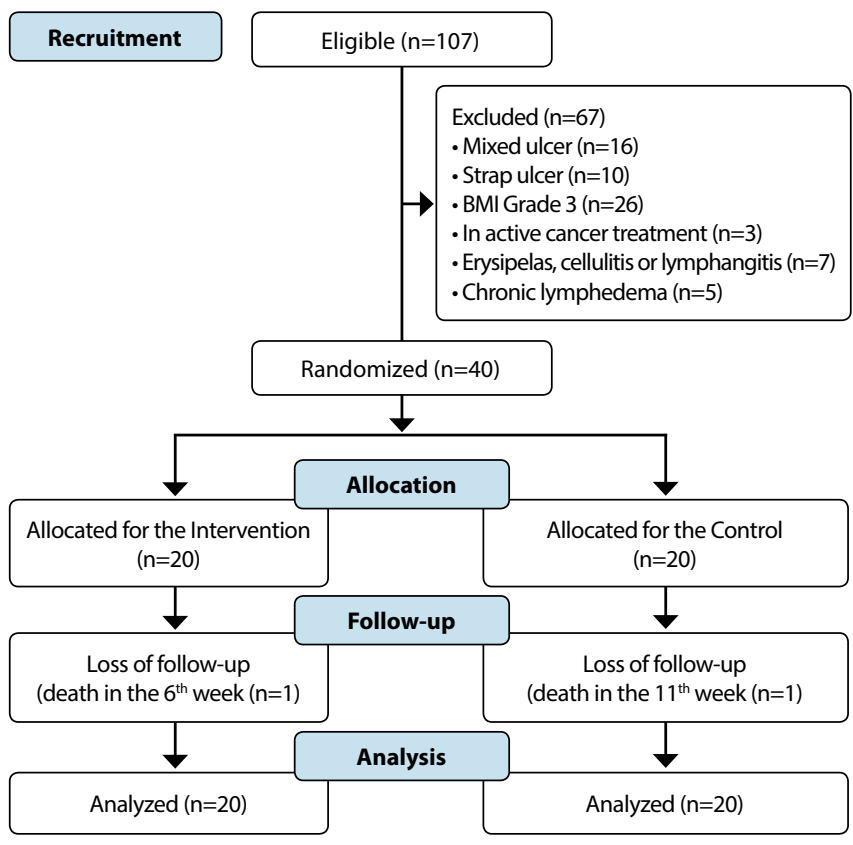

Figure 1 - CONSORT diagram of allocation, follow-up and analysis, Porto Alegre, Rio Grande do Sul, Brazil, 2018 
Participants in both groups (intervention and control) had similar sociodemographic and clinical characteristics. The only statistically significant difference was regarding gender (Table 1).

Table 1 - Sociodemographic and clinical characteristics of patients $(n=40)$, Porto Alegre, Rio Grande do Sul, Brazil, 2018

\begin{tabular}{lccc}
\hline & $\begin{array}{c}\text { Intervention } \\
\text { group } \\
\mathbf{n = 2 0 ( 1 0 0 \% )}\end{array}$ & $\begin{array}{c}\text { Control } \\
\text { group } \\
\mathbf{n = 2 0 ( 1 0 0 \% )}\end{array}$ & $\boldsymbol{p}$ \\
\hline Sociodemographic characteristics & & & \\
$\quad$ Gender (female) & $17(85)$ & $9(45)$ & $0.019^{\dagger}$ \\
Age (years)* & $64.55 \pm 11.69$ & $63 \pm 12.25$ & 0.685 \\
White & $16(80)$ & $16(80)$ & 1.000 \\
Marital status (married) & $12(65)$ & $10(50)$ & 0.570 \\
Years of study (up to 8 years) & $15(75)$ & $12(63.2)$ & 0.501 \\
Following the consultation & $8(40)$ & $5(25)$ & 0.501 \\
Regular walks & $7(35)$ & $7(35)$ & 1.000 \\
Regular isometric exercise & $14(70)$ & $13(65)$ & 1.000 \\
Limb elevation & $18(90)$ & $16(80)$ & 0.661 \\
Clinical characteristics & & & \\
Body mass index* & $31.43 \pm 4.40$ & $29 \pm 5.95$ & 0.230 \\
Hypertension & $14(70)$ & $12(60)$ & 0.741 \\
Analgesic use & $14(73.7)$ & $17(85)$ & 1.000 \\
Current smoker & $5(25)$ & $4(20)$ & 0.150 \\
Ulcer venous characteristics & & & \\
$\quad$ Duration (> 1 to 5 years) & $8(40)$ & $8(40)$ & 1.000 \\
Number of ulcers (one) & $11(55)$ & $7(35)$ & 0.105 \\
\hline
\end{tabular}

Data expressed as absolute and relative frequency ( $p$-value by Fisher's exact test), unless otherwise indicated; *Mean and standard deviation (Student's $t$-test); ${ }^{+} P$-values $<0.05$ were considered statistically significant

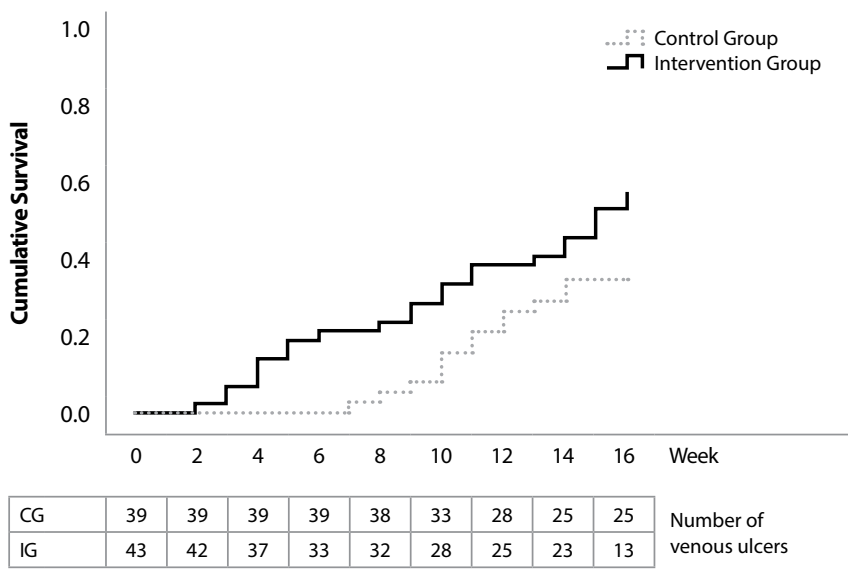

Figure 2 - Venous ulcers assessed and healed over 16 weeks, Porto Alegre, Rio Grande do Sul, Brazil, 2018
The healing of the first ulcer in the IG was observed in the second week of treatment, with 25 ulcers (58.1\%) healed at the end of the study. In the CG, the first ulcer healed only in the seventh week, and 13 ulcers (35.8\%) had healed by the end of the study period. This difference between groups was statistically significant $(p=0.031)$. Figure 2 shows a Kaplan-Meier curve of the results of interest.

The IG had a significant improvement in the overall mean score for the Wound Healing: Secondary Intention (1103) outcome compared to the CG ( $1=0.018)$. In an individual analysis of the indicators of this NOC outcome, statistically significant differences between the groups were observed in four of them, all in favor of the IG: decreased wound size $(p=0.010)$, scar formation $(p=0.034)$, granulation $(p=0.010)$, and exudate $(p=0.011)$ (Table 2$)$.

The overall mean score for the NOC outcome Wound Healing: Secondary Intention (1103) in the first consultation $(2.87 \pm 0.05)$ was higher in the CG. However, at the end of follow-up, the

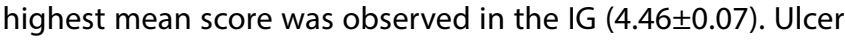
healing behavior also followed an upward trend over time in both groups, but with an earlier and more consistent rise in mean scores in the IG.

Progression of VU healing was also assessed by the NOC Tissue Integrity: Skin \& Mucous Membranes score (1101), which consists of six clinical indicators. Although the highest mean scores were observed in the IG, there was no statistically significant difference between the groups in the overall mean score.

However, there was a statistically significant difference between the groups in thickness, hydration and abnormal pigmentation indicators, when assessed individually (Table 3).

The highest overall mean score for the NOC outcome Tissue Integrity: Skin \& Mucous Membranes (1101) at the first visit was again observed in the CG $(3.74 \pm 0.06)$, but at the final visit of the study, a higher mean score was achieved in the IG (4.29 \pm 0.05$)$. Again, an upward trend of consistent improvement in mean scores was observed in the IG compared to the CG, in which scores varied more during the study.

\section{DISCUSSION}

This was the first study conducted by nurses that used a standardized outcome assessment instrument (NOC, specifically) to assess the therapeutic effect of LLLT on the VU tissue repair process.

Table 2 - Mean scores for the Nursing Outcomes Classification outcome Wound Healing: Secondary Intention (1103) and its indicators, Porto Alegre, Rio Grande do Sul, Brazil, 2018

\begin{tabular}{|c|c|c|c|c|c|}
\hline \multirow{2}{*}{ Outcome and indicators } & \multicolumn{2}{|c|}{ Intervention group } & \multicolumn{2}{|c|}{ Control group } & \multirow{2}{*}{$p$} \\
\hline & Week 1 & Week 16 & Week 1 & Week 16 & \\
\hline Wound Healing: Secondary Intention (1103) & $2.67(0.05)$ & $4.46(0.07)$ & $2.87(0.05)$ & $4.21(0.09)$ & 0.018 \\
\hline Decreased wound size (110321) & $1.00(0.00)$ & $3.79(1.61)$ & $1.05(0.32)$ & $3.13(1.59)$ & $0.010^{+}$ \\
\hline Scar formation (110320) & $1.19(0.58)$ & $4.37(0.84)$ & $1.72(0.72)$ & $4.03(0.95)$ & $0.034^{\dagger}$ \\
\hline Granulation (110301) & $3.19(1.20)$ & $4.84(0.43)$ & $3.51(0.97)$ & $4.51(0.75)$ & $0.010^{+}$ \\
\hline Foul wound odor (110317) & $3.65(0.68)$ & $4.86(0.35)$ & $3.75(0.88$ & $4.77(0.48)$ & 0.269 \\
\hline Macerated skin (110311) & $3.42(1.07)$ & $4.60(0.66)$ & $3.59(0.81)$ & $4.64(0.58)$ & 0.749 \\
\hline Surrounding skin erythema (110307) & $3.88(1.36)$ & $4.26(0.79)$ & $2.92(1.06)$ & $4.15(1.13)$ & 0.325 \\
\hline Periwound edema (110308) & $3.07(1.29)$ & $4.56(0.73)$ & $3.26(0.91)$ & $4.41(1.01)$ & 0.201 \\
\hline Exudate* & $3.02(0.74)$ & $4.42(0.76)$ & $3.23(0.58)$ & $4.05(0.82)$ & $0.011^{+}$ \\
\hline
\end{tabular}

The generalized estimation equation method was used to assess the interaction between time and groups, with values expressed as mean (standard error); ${ }^{*}$ Exudate: a composite of the indicators Purulent Drainage (110303), Serous Drainage (110304), Sanguineous Drainage (110305), and Serosanguineous Drainage (110306); ${ }^{+} P$-values $<0.05$ were considered statistically significant. 
Table 3 - Mean scores for the Nursing Outcomes Classification outcome Tissue Integrity: Skin \& Mucous Membranes (1101) and its indicators, Porto Alegre, Rio Grande do Sul, Brazil, 2018

\begin{tabular}{lccccc}
\hline \multirow{2}{*}{ Outcome and indicators } & \multicolumn{2}{c}{ Intervention group } & \multicolumn{2}{c}{ Control group } \\
& Week 1 & Week 16 & Week 1 & Week 16 & p \\
\hline Integridade Tissular: Pele e Mucosas (1101) & $3.43(0.06)$ & $4.29(0.05)$ & $3.74(0.06)$ & $4.27(0.07)$ & 0.385 \\
$\quad$ Espessura (110109) & $3.95(0.21)$ & $4.58(0.49)$ & $3.92(0.27)$ & $4.36(0.48)$ & $0.010^{\dagger}$ \\
Hidratação(110104) & $3.37(0.84)$ & $4.42(0.54)$ & $3.85(0.98)$ & $4.54(0.55)$ & $0.015^{+}$ \\
Pigmentação anormal (110105) & $2.49(0.88)$ & $3.50(0.97)$ & $2.95(0.72)$ & $3.72(0.99)$ & $0.008^{+}$ \\
Necrose (110123) & $4.75(0.44)$ & $4.95(0.22)$ & $4.95(0.22)$ & $4.93(0.26)$ & - \\
Dor* & $2.79(1.40)$ & $4.35(1.08)$ & $2.31(1.23)$ & $3.90(1.35)$ & 0.287 \\
Prurido* & $3.26(1.04)$ & $4.26(0.90)$ & $4.28(0.75)$ & $4.33(0.77)$ & 0.415 \\
\hline
\end{tabular}

The generalized estimation equation method was used to assess the interaction between time and groups, with values expressed as mean (standard error); *The Pain and Pruritus indicators, although not officially part of the NOC outcome Tissue Integrity: Skin \& Mucous Membranes (1101), were included on the basis of previous research ${ }^{(20) ;}{ }^{+} P$-values $<0.05$ were considered statistically significant.

The repair of this ulcer is influenced by local and systemic factors (in all patients). Healing occurs by second intention, a slow process that carries a risk of infection, ineffective scar formation and retraction, and a high cost of treatment ${ }^{(23-24)}$. The present study showed that this process can be improved by adjuvant LLLT which, when combined with conventional treatment, produces superior wound healing results and, consequently, improves patient comfort. This result was similar to that found in the literature, with the use of this therapy in the treatment of other types of chronic injuries ${ }^{(4-8,15,25-28)}$.

The use of clinical outcome indicators Wound Healing: Secondary Intention (1103) and Tissue Integrity: Skin \& Mucous Membranes (1101) demonstrated the positive therapeutic effect of LLLT, promoting and accelerating the process of structural and tissue regeneration, with a positive impact on the wound bed and edges and perilesional skin.

This effect can be seen in their decreased wound size and scar formation indicators, combined with the thickness indicator of the outcome Tissue Integrity: Skin \& Mucous Membranes (1101), capable to showing whether wound contraction is occurring by centripetal movement of the wound edges (total thickness). This is considered one of the variables of the effect of a wound treatment (in this case, LLLT). A statistically significant difference was observed in this indicator, according to the international literature, which developed a risk stratification system for VU and to identify which ones require adjuvant therapies ${ }^{(26)}$.

LLLT has the photobiochemical action effect of low-power laser irradiation, combined with the release of preformed substances, which stimulate ATP production and suppress the production of prostaglandins, leading to a reduction in the inflammatory state. Its photobiophysical and photobiological effects also stimulate macrophages to release epidermal growth factor, promoting the proliferation and migration of epithelial cells and keratinocytes ${ }^{(6)}$. The outcomes showed that local red laser irradiation significantly accelerates the healing process in the graft donor area for the treatment of burn patients ${ }^{(6)}$.

Another point that is biostimulated with irradiation is the wound edges, synthesizing fibronectin, which forms a temporary matrix to which cells can migrate and regenerate ${ }^{(6,26)}$. These effects imply quality scar tissue when LLLT is applied, being superior to conventionally treated VU, as can be seen in the outcomes of this clinical study.

The application of LLLT stimulated neovascularization, generating an adequate capillary blood supply, which resulted in viable granulation tissue for wound bed repair, as demonstrated by the behavior of the granulation indicator over this time. Also, due to its biomodulating action, it can reduce the amount of inflammatory infiltrate, shown by the exudate indicator score. This result was similar to the effects found in the repair of burnt tissue, pressure injury and diabetic ulcers, which highlighted that irradiation provides an environment conducive to the healing process ${ }^{(6,15,25-26)}$.

In this study, LLLT may have induced an organic restorative reaction in areas of destroyed or lost tissue. This characteristic property of laser therapy allows the wound bed to be filled with tissue identical to the original; this is not merely a repair, but a true regeneration of skin integrity. The improvements observed in the scar formation indicator of the outcome Wound Healing: Secondary Intention (1103) and the hydration indicator of the outcome Tissue Integrity: Skin \& Mucous Membranes (1101) are consistent with this process ${ }^{(6,26-28)}$.

Descriptive analysis of each patient's wound condition, as measured by relevant clinical indicators of NOC outcomes, revealed a significant positive impact of adjuvant LLLT on wound healing compared to standard treatment alone.

\section{Study limitations}

Among the limitations are the exclusion of patients with circumferential ulcers and/or BMI in the Grade 3 obesity range, which represents a significant part of the population with vascular alterations. Although sample size can be considered a limitation, its calculation was performed based on the change in the score of NOC indicators, which reinforces the results presented.

\section{Contributions to nursing, health, and public policies}

The results of this study contribute to the advancement of wound care and nursing classifications in clinical practice. Furthermore, this research can support the development of other studies in different types of wounds as well as in other clinical settings.

\section{CONCLUSIONS}

The study concluded that the group that received application of LLLT adjuvant to standard treatment had a greater number of healed VU and in less time, with better epithelial tissue when compared to the control group.

Moreover, the use of a standardized system, NOC, helped to assess and analyze the healing process of these ulcers and related 
outcomes, helping nurses to implement nursing interventions for patients with VU. The evidence generated by this study supports the incorporation of LLLT into new wound care protocols, specific to $\mathrm{VU}$, and also for use in a variety of settings.

\section{FUNDING}

This research is supported by the Brazilian National Council for Scientific and Technological Development (CNPq - Conselho Nacional de Desenvolvimento Científico e Tecnológico) and the Research Incentive Fund (FIPE-HCPA).

\section{ACKNOWLEDGMENT}

We would like to thank the research team and the outpatient nursing service at Hospital de Clínicas de Porto Alegre.

\section{SUPPLEMENTARY MATERIAL}

Paper extracted from doctoral dissertation "O efeito do laser de baixa potência no tratamento de úlceras venosas avaliado pela Nursing Outcomes Classification (NOC): ensaio clínico" available at: http://hdl.handle.net/10183/186135.

\section{REFERENCES}

1. Davies AH. The seriousness of chronic venous disease: a review of real-world evidence. Adv Ther. 2019; 36(Suppl 1):5-12. https://doi. org/10.1007/s12325-019-0881-7

2. Marinel LO, Roura J, Verdú Soriano J. National consensus conference about lower limbs ulcers (C.O.N.U.E.I.) [Internet]. 2018 [cited 2020 Sep 17]. Available from: https://gneaupp.info/wp-content/uploads/2018/04/CONUEIX2018.pdf

3. Hoddea JP, Hilesa MC, Metzgerb DW. Characterization of the local wound environment following treatment of chronic leg ulcers with SIS wound matrix. J Tissue Viability. 2020;2-47. https://doi.org/10.1016/j.jtv.2019.12.003

4. Machado RS, Viana S, Sbruzzi G. Low-level laser therapy in the treatment of pressure ulcers: systematic review. Lasers Med Sci. 2017; 32(4):937-44. https://doi.org/10.1007/s10103-017-2150-9

5. Mathur RK, Sahu K, Saraf S, Patheja P, Khan F, Gupta PK. Low-level laser therapy as an adjunct to conventional therapy in the treatment of diabetic foot ulcers. J Lasers Med Sci. 2017;32(2):247-82. https://doi.org/10.1007/s10103-016-2019-2

6. Vaghardoost R, Momeni M, Kazemikhoo N, Mokmeli S, Dahmardehei M, Ansari F, et al. Effect of low-level laser therapy on the healing process of donor site in patients with grade 3 burn ulcer after skin graft surgery (a randomized clinical trial). Lasers Med Sci, 2018;33(3):6037. https://doi.org/10.1007/s10103-017-2430-4

7. Bavaresco T, Osmarin VM, Pires A, Moraes, V, Lucena AF. Low-power laser therapy in wound healing. Rev Enferm UFPE. 2019;13(1):216-26. https://doi.org/10.5205/1981-8963-v01i01a235938p216-226-2019

8. Vitse J, Bekara F, Byun S, Herlin C, Teot L. A double-blind, placebo-controlled randomized evaluation of the effect of low-level laser therapy on venous leg ulcers. Int J Low Extrem Wounds. 2017;16(1):29-35. https://doi.org/10.1177\%2F1534734617690948

9. Chamanga ET. Clinical management of non-healing wounds. Nurs Stand, 2018;32(29):48-63. https://doi.org/107748/ns.2018.e10829

10. National Pressure Injury Advisory Panel (NPIAP). NPIAP Position Statements on preventing injury with N95 masks [Internet]. 2019 [cited 2020 Sep 17]. Available from: https://cdn.ymaws.com/npiap.com/resource/resmgr/position_statements/Mask_Position_Paper_FINAL_fo.pdf

11. Cho SK, Mattke S, Gordon H, Ennis MSW. Development of a model to predict healing of chronic wounds within 12 weeks. Adv Wound Care. 2020;9(9):516-24. https://doi.org/10.1089/wound.2019.1091

12. Garbuio DC, Zamarioli CM, Silva NCM, Oliveira-Kumakura ARS, Carvalho EC. Instrumentos para avaliação da cicatrização de lesões de pele: revisão integrativa. Rev Eletron Enferm. 2020;20:20-40. https://doi.org/10.5216/ree.v20.49425

13. Moorhead S, Johnson M, Maas M, Swanson E. Nursing outcomes classification (NOC): measurement of health outcomes. 6th ed. Philadelphia: Elsevier; 2018. 776 p.

14. Menna Barreto LN, Silva MB, Engelman B, Figueiredo MS, Rodrigues-Acelas AL, Cañon-Montañez W, et al. Evaluation of surgical healing in orthopedic patients with impaired tissue integrity according to Nursing Outcomes Classification. Int J Nurs Terminol Knowledge. 2019;30:228-33. https://doi.org/10.1111/2047-3095.12233

15. Palagi S, Severo IM, Menegon DB, Lucena AF. Laser therapy in pressure ulcers: evaluation by the Pressure Ulcer Scale for Healing and Nursing Outcomes Classification. Rev Esc Enferm USP. 2015;49(5):826-33. https://doi.org/10.1590/S0080-623420150000500017

16. Osmarin VM, Boni FG, Bavaresco T, Lucena AF, Echer IC. Use of the Nursing Outcomes Classification - NOC to assess the knowledge of patients with venous ulcer. Rev Gaúcha Enferm. 2020;41(supp):e20190146. https://doi.org/10.1590/1983-1447.2020.20190146

17. Luzia MF, Vidor ID, Silva ACFE, Lucena AF. Fall prevention in hospitalized patients: evaluation through the nursing outcomes classification/ NOC. Applied Nurs Res. 2020;54. https://doi.org/10.1016/j.apnr.2020.151273

18. Bavaresco T, Pires AUB, Moraes VM, Osmarin VM, Silveira DT, Lucena AF. Low-level laser therapy for treatment of venous ulcers evaluated with the Nursing Outcome Classification: study protocol for a randomized controlled trial. Trials. 2018;19(1):372. https://doi.org/10.1186/s13063-018-2729-x

19. Guimarães LSP, Hirakata VN. Use of the Generalized Estimating Equation Model in longitudinal data analysis. Clin Biomed Res[Internet]. 2013 [cited2021May 03];32(4):503-511. Available from: https://seer.ufrgs.br/hcpa/article/view/36971 
20. Almeida ABM, Queiroz Frazão CMF, Sá Tinôco JD, Paiva MGMN, Lopes MVO, Lira ALBC. Venous ulcer: risk factors and the Nursing Outcomes Classification. Invest Educ Enferm, 2014;32(2):252-9. https://doi.org/10.17533/udea.iee.v32n2a08

21. Oliveira FP, Oliveira BGB, Santana RF, Silva BP, Cândido JSC. Nursing interventions and outcomes classifi cations in patients with wounds: cross-mapping. Rev Gaúcha Enferm, 2016;37(2):e55033. https://doi.org/10.1590/1983-1447.2016.02.55033

22. Cazzell SM, Lange DL, Dickerson Jr JE, Slade HB. The management of diabetic foot ulcers with porcine small intestine submucosa tri-layer matrix: a randomized controlled trial. Adv Wound Care. 2015;4(12):711-18. https://doi.org/10.1089/wound.2015.0645

23. Silva JR, Burger B, Kühl CMC, Candreva T, Anjos MBP, Rodrigues HG. Wound Healing and Omega-6 Fatty Acids: from inflammation to repair. Mediators Inflamm. 2018;2018:2503950. https://doi.org/10.1155/2018/2503950

24. Moura JPG, Brandão LB, Barcessat ARP. Estudo da Terapia Fotodinâmica (PDT) no reparo de lesões teciduais: estudo de casos clínicos. Scientific Station (UNIFAP). 2018;8(1):103-10. https://doi.org/10.18468/estcien.2018v8n1.p103-110

25. Tchanque-Fossuo CN, Ho D, Dahle SE, Koo E, Li C. A systematic review of low-level light therapy for treatment of diabetic foot ulcer. Wound Repair Regen. 2016;24(2):418-26. https://doi.org/10.1111/wrr.12399

26. Fife C, Horn SD. The wound healing index for predicting venous leg ulcer outcome. 2020;1;9(2):68-77. https://doi.org/10.1089/ wound.2019.1038

27. Feitos MCP, Carvalho AFM, Feitosa VC, Coelho IM, Oliveira RA. Arisawa EAL. Effects of the Low-Level Laser Therapy (LLLT) in the process of healing diabetic foot ulcers. Acta Cir Bras. 2015;30(12):852-57. https://doi.org/10.1590/S0102-86502015120000010

28. Andrade FSSD, Clark RMO, Ferreira ML. Effects of low-level laser therapy on wound healing. Rev Col Bras Cir. 2014;41(2):129-33. https://doi. org/10.1590/S0100-69912014000200010 